\title{
PENYELESAIAN KREDIT MACET \\ DENGAN JAMINAN SERTIFIKAT HAK MILIK ATAS TANAH MENURUT \\ UNDANG - UNDANG NOMOR 04 TAHUN 1996 \\ TENTANG HAK TANGGUNGAN
}

\author{
Oleh \\ Jatmiko Winarno \\ Dosen Fakultas Hukum Universitas Islam Lamongan
}

\begin{abstract}
ABSTRAK
Dalam Undang - Undang Perbankan No. 7 Tahun 1992 disebutkan bahwa pengertian bank adalah suatu badan usaha yang menghimpun dana dari masyarakat dalam bentuk simpanan dan menyalurkan kepada masyarakat dalam bentuk kredit atau bentuk-bentuk lainnya, dalam rangka meningkatkan taraf hidup rakyat banyak adanya aturan hukum mengenai pelaksanaan pembebanan Hak Tanggungan dalam suatu perjanjian kredit bertujuan untuk memberikan perlindungan hukum bagi semua pihak dalam memanfaatkan tanah beserta benda - benda yang berkaitan dengan tanah sebagai jaminan kredit. Salah satunya adalah Undang-undang No. 4 Tahun 1996 tentang Hak Tanggungan, yang mengatur tentang perjanjian antara pihak piutang dan berhutang, sebagaimana telah diketahui, kredit macet merupakan persoalan serius yang dihadapi industri perbankan di Indonesia untuk itu, praktik pengikatan kredit dengan jaminan Hak Tanggungan dalam kegiatan perbankan hendaknya dapat pula dilaksanakan sesuai dengan apa yang telah diatur dalam Undang - Undang Hak Tanggungan. Permasalahan yang akan diteliti adalah "Penyelesaian Kredit Macet Dengan Jaminan Sertifikat Hak Milik Atas Tanah Menurut Undang - Undang Nomor 04 Tahun 1996 tentang Hak Tanggungan", serta hambatan - hambatan yang dihadapi dalam penyelesaian kredit macet beserta cara mengatasinya. Metode yang digunakan dalam penelitian hukum ini adalah Penelitian yuridis normatif (hukum normative). Setiap bank hendaknya menilai secara mendalam kelima faktor prinsip dasar sebelum memberikan keputusan kredit pada calon kreditur, sehingga dapat diperoleh keyakinan dari itikad baik nasabah dan kesanggupan untuk melunasi hutangnya. Dari penelitian yang dilakukan ini diperoleh hasil mengenai tata cara menyelesaikan kredit macet yang dijamin dengan sertifikat atas tanah sebagai jaminan pelunasan utang tertentu.
\end{abstract}

\section{Kata kunci : Hak Tanggungan, Kredit Macet}

\subsection{PENDAHULUAN}

\section{Latar Belakang}

Dalam kehidupan manusia

memerlukan dana agar dapat

menggerakkan roda ekonomi yang dirasakan setiap hari makin meningkat. banyak masyarakat yang mempunyai banyak dana tetapi tidak memiliki sebuah kemampuan dalam menggunakan dana tersebut, tapi disisi lain ada banyak kelompok masyarakat yang punya kemampuan untuk berusaha tapi terhambat

oleh kendala karena terbatasnya dana yang dimiliki atau mungkin tidak memiliki dana sama sekali. Untuk itu keduanya memerlukan intermediary yang bertindak sebagai kreditur dan sebagai penyedia dana bagi debitur, dari sinilah akan timbul yang namanya sebuah perjanjian yaitu utang piutang atau pemberian kredit, dan Lembaga sebagai penyedia keuangan disini ada 2 (dua) yakni : 
1. Lembaga Keuangan bank, maksud lembaga keuangan ini adalah lembaga keuangan yang berwujud bank.

2. Lembaga keuangan bukan bank, tidak berarti lembaga keuangan ini tidak melakukan kegiatan keuangan seperti halnya yang dilakukan oleh bank, hanya saja lembaga keuangan ini merupakan lembaga yang memberikan jasa dalam hal keuangan namun bukan merupakan bank.

Bank adalah "bagian dari sistem keuangan dan sistem pembayaran suatu Negara, bahkan pada era globalisasi sekarang ini bank telah menjadi bagian dari sistem keuangan dan sistem pembayaran dunia. Mengingat hal yang demikian itu, maka begitu suatu bang memperoleh izin berdiri dan beroperasi dari otoritas moneter Negara yang bersangkutan bank tersebut menjadi milik masyarakat. Oleh karena itu eksistensinya bukan saja harus dijaga oleh para pemilik bank itu sendiri tetapi juga oleh masyarakat nasional dan global". ${ }^{1}$ Dalam pasal (1) Undang - Undang Perbankan Nomor 10 Tahun 1998 disebutkan bahwa kredit yaitu penyediaan uang atau

tagihan yang dapat dipersamakan dengan itu, berdasarkan persetujuan atau kesepakatan pinjam - meminjam antara bank dengan pihak lain yang mewajibkan pihak peminjam melunasi utangnya setelah jangka waktu tertentu dan pemberian bunga. Secara sederhana bank dapat pula diartikan sebagai "Lembaga Keuangan yang kegiatan usahanya adalah menghimpun dana dari masyarakat dan menyalurkan kembali dana tersebut ke masyarakat serta memberikan jasa - jasa bank lainnya", ${ }^{2}$ sedangkan dalam Undang Undang Perbankan Nomor 7 Tahun 1992 disebutkan bahwa bank adalah suatu badan usaha yang menghimpun dana dari masyarakat dalam bentuk simpanan dan menyalurkan kepada masyarakat dalam bentuk kredit atau bentuk-bentuk lainnya dalam rangka meningkatkan taraf hidup rakyat banyak.
Seseorang yang menyimpan atau uang di bank disebut nasabah bank sedangkan masyarakat yang butuh dana dari bank disebut debitur, dalam kesepakatan perjanjian antara perbankkan dan pihak peminjam mengharuskan pihak peminjam atau sebagai debitur melunasi hutangnya dan bunga sesuai dengan perjanjian, ketentuan ini harus dengan sebuah perikatan perjanjian terlebih dahulu, "Dalam bahasa latin kredit disebut "credere" yang artinya percaya, maksudnya pemberi kredit percaya kepada penerima kredit bahwa kredit yang disalurkannya pasti akan kembali sesuai perjanjian, sedangkan bagi penerima kredit berarti menerima sebuah kepercayaan, sehingga mempunyai kewajiban membayar kembali pinjaman tersebut sesuai dengan jangka waktunya. ${ }^{3}$

Kegiatan menyalurkan kredit pada masyarakat tidaklah mudah dan mengandung banyak sekali resiko, karena dapat mempengaruhi kelangsungan usaha perbankkan, untuk mengurangi resikonya bank meminta sebuah jaminan kredit dalam artian harus sanggup dan juga mampu melunasi hutangnya atau kewajibannya sesuai dengan yang telah disepakati dengan perikatan perjanjian sebelum memberi kredit. Jaminan adalah jaminan kebendaan yang objeknya adalah benda milik debitur, yaitu kesanggupan pihak ketiga untuk memenuhi kewajiban debitur. Tujuan dari penilaian tersebut adalah agar kredit yang diberikannya benar benar aman. Dalam pasal 1 butir 1 Undang -Undang Nomor 4 tahun 1996 tentang hak tanggungan atas tanah beserta benda benda yang berkaitan dengan tanah, yang selanjutnya disebut "Hak Tanggungan" adalah hak jaminan yang dibebankan pada hak atas tanah sebagaimana dimaksud dalam Undang - Undang Nomor 5 Tahun 1960 tentang Peraturan Dasar Pokok Pokok Agraria berikut atau tidak benda benda lain yang merupakan satu kesatuan dengan tanah itu, untuk pelunasan utang tertentu yang memberikan kedudukan 
yang diutamakan kepada kreditur tertentu terhadap kreditur - kreditur lain, ${ }^{4}$

Kemudian lahirlah Undang - Undang Hak Tanggungan sebagai jaminan, dalam Undang - Undang Nomor 4 Tahun 1996 tentang Hak Tanggungan pasal (10) "menentukan bahwa pemberian Hak Tanggungan didahului dengan janji untuk memberikan Hak Tanggungan sebagai jaminan pelunasan utang tertentu yang dituangkan didalam dan merupakan bagian tak terpisahkan dari perjanjian utang piutang yang bersangkutan atau perjanjian lain yang menimbulkan utang tersebut. Pemberian Hak Tanggungan dilakukan dengan pembuatan Akta Pemberian Hak Tanggungan oleh PPAT sesuai dengan peraturan perundang - undangan yang berlaku". "Selanjutnya dalam penjelasan umum Undang - Undang Hak Tanggungan adalah Hak Jaminan atas tanah untuk pelunasan utang tertentu, yang memberikan kedudukan diutamakan kepada kreditur tertentu terhadap kreditur lain, dalam arti bahwa jika debitur cidera janji, kreditur pemegang hak tanggungan berhak menjual melalui pelelangan umum tanah yang dijadikan jaminan menurut ketentuan peraturan perundang - undangan yang bersangkutan dengan hak mendahului dari pada kreditur - kreditur yang lain". ${ }^{6}$

Sebagai debitur yang cidera janji atau tidak menepati perjanjian yang telah dibuat, dalam hukum perjanjian debitur tersebut telah melakukan sebuah wanprestasi dengan segala akibat hukumnya dalam hal ini bisa dikatan sebagai kredit macet. "Untuk melindungi uang yang dikucurkan lewat kredit dari resiko kerugian pihak perbankan selaku kreditur membuat pagar pengaman, dalam kondisi sebaik apapun atau dengan analisis sebaik mungkin, resiko

kredit macet tidak dapat dihindari, pagar pengamanan yang dibuat biasanya berupa jaminan yang harus disediakan debitur.

\subsection{Rumusan Masalah}

Dari uraian latar belakang diatas, penulis dapat merumuskan dua permasalahan yang akan dibahas yaitu sebagai berikut :

1. Bagaimanahkah ketentuan penyelesaian kredit macet di bank menurut Undang - Undang Nomor 04 Tahun 1996 tentang Hak Tanggungan?

2. Bagaimana proses penyelesaian kredit macet dengan jaminan sempurna?

\subsection{Tujuan Penelitian}

Ada beberapa tujuan yang hendak dicapai dalam penulisan ini :

1. Untuk mengetahui tata cara ketentuan penyelesaian kredit macet di bank

2. Untuk mengetahui dan menganalisa bagaimanakah proses penyelesaian kredit macet dengan jaminan sempurna

\section{METODE PENELITIAN}

Tipe penelitian hukum yang digunakan adalah yuridis normatif. Metode penelitian yuridis normative adalah suatu prosedur penelitian ilmiah untuk menemukan kebenaran berdasarkan logika keilmuan dari sisi Normatifnya. Oleh karena tipe penelitian yang digunakan penulis adalah tipe penelitian yuridis normatif, maka pendekatan yang digunakan adalah pendekatan perundang - undangan (Statuory Approach). Dan dalam metode pendekatan perundang - undangan peneliti perlu memahami hierarkhi dan asas - asas dalam peraturan perundang - undangan. Penulis menggunakan metode pendekatan secara yuridis normatif khususnya dalam pendekatan Perundang - undangan (Statuory Approach) yang nantinya akan dikaitkan dengan Undang-undang Nomor 4 Tahun 1996 tentang Hak Tanggungan.

\section{HASIL DAN PEMBAHASAN}

Dalam Undang - Undang Nomor 7 tahun 1992 tentang Perbankan "Kredit adalah penyediaan uang atau tagihan yang dapat dipersamakan dengan itu, berdasarkan persetujuan atau kesepakatan 
pinjam - meminjam antar bank dengan pihak lain yang mewajibkan pihak peminjam untuk melunasi utangnya setelah jangka waktu tertentu dengan imbalan atau bagi hasil. Dalam bahasa latin kredit disebut "Credere" yang artinya percaya, maksudnya si pemberi kredit percaya kepada si penerima kredit bahwa kredit yang disalurkan pasti akan dikembalikan sesuai perjanjian, sedangkan bagi si penerima kredit berarti menerima kepercayaan, sehingga mempunyai kewajiban untuk membayar kembali pinjaman tersebut.

Kredit Macet adalah kredit yang angsuran pokok dan bunganya tidak dapat dilunasi selama lebih dari 2 (dua) masa angsuran ditambah 21 bulan, atau penyelesaian kredit telah diserahkan kepada pengadilan atau telah diajukan ganti rugi kepada Perusahaan Asuransi Kredit (Joyosumarto dalam Naja, 2005 : 329). Kredit macet adalah kredit yang tidak lancar dan telah sampai pada jatuh temponya belum dapat juga diselesaikan oleh nasabah yang bersangkutan (Sinungan, 1993:57) menyatakan bahwa kredit macet adalah "kesulitan keuangan yang dialami oleh debitur". Penyebab kesulitan keuangan dapat dikategorikan menjadi 2 yaitu :

a. Faktor Interen yaitu kelemahan dalam kebijaksanaan pembelian dan penjualan, tidak efektifnya kontrol atas biaya pengeluaran, kebijaksanaan tentang piutang yang tidak efektif, Permodalan yang tidak cukup.

b. Faktor Ekteren : biasanya karena bencana alam, Peperangan, Perubahan kondisi perekonomian dan sebagainya.

Ada beberapa faktor yang mempengaruhi terjadinya kredit macet yaitu :

1. Nasabah menyalahgunakan kredit yang diperoleh

2. Nasabah kurang mampu mengelola usaha

3. Nasabah beritikad tidak baik

Timbulnya kredit bermasalah (macet) selain berasal dari nasabah dapat juga dari bank, karena bank tidak terlepas dari kelemahan yang dimilikinya. hal tersebut karena dalam melakukan analisis pihak bank kurang teliti sehingga apa yang seharusnya terjadi tidak diprediksi sebelumnya. Kasmir (2004:115). Hal kelalaian atau wanprestasi pada pihak si berhutang ini harus dinyatakan dahulu secara resmi, yaitu dengan memperingatkan, bahwa si berpiutang menghendaki pembayaran seketika atau dalam jangka waktu yang pendek (Subekti, 2003:147).

Berdasarkan Surat Edaran Bank Indonesia Nomor 26/4/BPP tanggal 29 Mei. 1993 dikatakan bahwa kredit digolongkan macet apabila:

1. Tidak memenuhi kriteria lancar, kurang lancar dan diragukan

2. Memenuhi kriteria diragukan tetapi dalam jangka waktu 21 bulan sejak digolongkan diragukan belum ada pelunasan atau usaha penyelamatan kredit;

3. Kredit tersebut penyelesaiannya telah diserahkan kepada Pengadilan Negeri atau Badan Urusan Piutang Negara (BUPN) atau telah diajukan penggantian ganti rugi kepada perusahaan asuransi kredit.

Dalam kredit macet pihak bank perlu melakukan penyelamatan, sehingga tidak akan menimbulkan sebuah kerugian. Penyelamatan terhadap kredit macet dilakukan dengan cara antara lain :

1. Recheduling : tindakan dengan cara memperpanjang jangka waktu kredit atau waktu angsuran.

2. Reconditioning : bank mengubah berbagai persyaratan yang ada.

3. Penurunan suku bunga yaitu agar lebih meringankan beban nasabah.

4. Restructuring tindakan bank kepada nasabah dengan cara menambah modal nasabah

5. Kombinasi : dari ke tiga jenis yang diatas. Seorang nasabah dapat saja diselamatkan dengan kombinasi antara Rescheduling dengan Restructuring, 
6. Penyitaan jaminan : jalan terakhir apabila nasabah sudah tidak punya itikad baik ataupun sudah tidak mampu lagi untuk membayar semua utangnya

Kredit bermasalah selalu ada dalam kegiatan perkreditan bank karena bank tidak mungkin menghindarkan adanya kredit bermasalah, bank hanya berusaha menekan seminimal mungkin besarnya kredit bermasalah agar tidak melebihi ketentuan Bank Indonesia sebagai pengawas perbankan. Kredit bermasalah tidak dapat dipersamakan dengan kredit macet, kredit bermasalah adalah kredit yang memiliki kolekbilitas diragukan dan mempunyai potensi macet, sedangkan kredit macet adalah angsuran pokoknya tidak dapat dilunasi lebih dari 2 (dua) masa angsuran ditambah 21 (dua puluh satu) bulan sehingga penyelesaian kreditnya diserahkan pengadilan. Upaya penyelesaian kredit macet tidak memberi alternatif lain selain melakukan eksekusi atas agunan kredit debitur atau penjamin maupun dengan mengajukan gugatan melalui lembaga pengadilan. Secara garis besar upaya penanganan kredit bermasalah dapat ditempuh melalui 2 (dua) upaya tempuh yaitu melalui tindakan :

1. Penyelamatan kredit.

2. Penyelesaian kredit.

Penyelamatan kredit adalah upaya penanganan kredit bermasalah yang sifatnya sementara "temporer" karena apbila upaya ini gagal maka yang ditempuh adalah upaya penyelesaian kredit. Penyelesaian kredit bermasalah merupakan upaya terakhir dari bank untuk melakukan upaya pengembalian kredit debitur baik dengan upaya eksekusi agunan kredit, penagihan kredit kepada penjamin, pengambil-alihan aguan kredit oleh bank, penjualan agunan secara sukarela, atau dengan upaya pengajuan gugatan secara perdata atas pelunasan kewajiban hutang debitur. Secara administratif, kredit yang diselamatkan adalah kredit yang semula tergolong kurang lancar dan diragukan macet yang kemudian diusahakan diperbaiki sehingga mempunyai kolekbilitas lancar. tindakan penyelamatan kredit dapat ditempuh dengan upaya :

a. Penjadwalan kembali atau disebut Rescheduling yaitu merubah syarat yang telah diperjanjikan dalam perikatan perjanjian kredit,

biasanya berhubungan dengan jangka waktu kredit ataupun jadwal pembayaran, baik besarnya jumlah atau nilai angsuran kredit.

b. Persyaratan kembali atau disebut Reconditioning, yaitu melakukan perubahan seluruhnya atau sebagian dalam syarat yang diperjanjian dan dibuat, dengan begitu tidak akan terbatas pada jadwal angsuran dan jangka waktu perkreditannya.

c. Penataan kembali atau disebut juga dengan Restructuring yaitu suatu usaha bank untuk melakukan perubahan persyaratan dalam suatu perjanjian kredit dengan berupa pemberian tambahan sebuah kredit dan atau melakukan konversi pada seluruh atau sebagian kredit menjadi equity perusahaan, yang dilakukan dengan atau tanpa Rescheduling dan Reconditioning.

Dalam Undang-Undang Pokok Agraria sebagai ketentuan dasar mengenai pokok-pokok Agraria di Negara kita dalam mengatur tentang masalah-masalah hakhak jaminan atas tanah telah menggariskan suatu ketentuan sebagaimana disebutkan dalam pasal 51 yang menyatakan bahwa "Hak Tanggungan" yang dapat dibebankan kepada Hak Milik, Hak Guna Usaha dan Hak Guna Bangunan tersebut dalam pasal 25, 33 dan 39 diatur dengan Undangundang. Selanjutnya dalam Pasal 25 UUPA dikatakan "Hak Milik dapat dijadikan jaminan hutang dengan dibebani Hak Tanggungan". Pasal 33 UUPA menyatakan "Hak Guna Usaha dapat dijadikan jaminan hutang dengan dibebani Hak Tanggungan dan Pasal 39 UUPA menyatakan "Hak Guna Bangunan dapat 
dijadikan jaminan hutang dengan dibebani Hak Tanggungan. ${ }^{7}$

Dalam UUP tidak tercantum secara tegas apa dasar hukum perjanjian kredit, hanya saja pengertian kredit sebagaimana yang dijabarkan dalam pasal 1 angka 13 UUP dapat disimpulkan dasar hukum pemberian kredit adalah perjanjian Berdasarkan Pasal 20 Undang-Undang Nomor 4 Tahun 1996 tentang Hak Tanggungan beserta benda-benda yang berkaitan dengan tanah (selanjutnya di sebut dengan UU HT), alternatif penyelesaian kredit macet yang dijamin dengan Hak Tanggungan dapat dilakukan dengan 3 alternatif antara lain:

1. Penjualan lelang objek Hak Tanggungan atas kekuatan sendiri oleh pemegang Hak Tanggungan pertama, melalui Kantor Lelang Negara di wilayah mana tanah yang dibebani Hak Tanggungan terletak serta mengambil pelunasan utangnya hasil penjualan lelang tersebut.

2. Parate Eksekusi (Lelang Objek Hak Tanggungan Melalui Pengadilan), Parate eksekusi merupakan pelaksanaan eksekusi melalui proses pengadilan. Jika debitur cidera janji, kreditor berhak atas pelunasan piutangnya melalui eksekusi dan umumnya eksekusi dilaksanakan melalui

pelelangan umum. Pasal 20 ayat (2) UUHT memberikan pengecualian dari ketentuan ayat (1) tersebut, dengan adanya kebebasan pemegang dan pemberi Hak Tanggungan untuk menjual obyek Hak Tanggungan secara di bawah tangan. Hal ini dapat dilakukan berdasarkan kesepakatan di antara mereka, dengan tujuan untuk memperoleh harga yang tinggi, dan menguntungkan semua pihak. Sedangkan jika melalui pelelangan umum akan sulit mencapai harga yang sesuai dengan keinginan mereka.

3. Penjualan Dibawah Tangan.
Pasal 20 ayat (2) UUHT memberikan pengecualian dari ketentuan ayat (1) tersebut, dengan adanya kebebasan pemegang dan pemberi Hak Tanggungan untuk menjual obyek Hak Tanggungan secara di bawah tangan. Hal ini dapat dilakukan berdasarkan kesepakatan di antara mereka, dengan tujuan untuk memperoleh harga yang tinggi, dan menguntungkan semua pihak.

Apabila diperhatikan metode analisis kredit yang digunakan oleh bank, tampak bahwa jaminan atau istilah lain yang sering digunakan ialah agunan, merupakan faktor yang cukup penting. Tapi perlu diingat juga bahwa agunan yang diberikan dalam rangka pemberian kredit dari kreditur kepada debitur sebagai perjanjian tambahan dalam arti bila debitur tidak mampu melunasi utangnya, maka agunan akan dilelang untuk melunasi pinjaman yang tidak dapat dibayar oleh debitur. Hal ini secara tegas dijabarkan dalam pasal 224 HIR, Surat Grossedari akta hipotek dan surat utang yang dibuat dihadapan notaris di Indonesia yang berkepala demi keadilan berdasarkan ketuhanan yang maha Esa berkekuatan sama dengan putusan hakim. Untuk itu bila dilihat dari tataran Normatif, apabila ada jaminan yang diikat dengan akta notaris, jika debitur tidak mampu melunasi utangnya maka jaminan dapat dieksekusi. Hal ini tentu menarik bagi dunia usaha perbankan. Seperti yang dikemukakan oleh Sutan Remy Sjahdeini, kalangan perbankan berpendapat dengan adanya klausul pengakuan utang maka grosse akta perjanjian kredit telah identik dengan grosse surat utang sebagaimana dimaksud dalam pasal 224 HIR. dengan demikian apabila debitur tidak melunasi utangnya (Wanprestasi) bank berdasarkan grosse akta yang bertitel eksekutorial : "Demi keadilan berdasarkan ketuhanan yang Maha Esa". Dapat langsung memohon eksekusi kepada pengadilan untuk memaksa debitur membayar utangnya kepada bank, tanpa harus melalui gugatan 
perdata ${ }^{8}$ Yang menjadi pertanyaan adalah apakah jaminan merupakan hal yang mutlak dalam pemberian kredit? bukankah dalam KUHPdt telah dikemukakan, perikatan yang dibuat oleh seseorang dijamin oleh harta benda yang dimilikinya baik yang telah ada maupun dikemudian hari. Hanya saja dalam hal ini, pihak kreditur harus membuktikan kebenaran haknya. Itulah sebabnya dibutuhkan jaminan dalam pemberian kredit.

Dalam hal ini menarik untuk mencermati apa yang dijabarkan

dalam Pasal 8 ayat (1) UUP, dalam memberikan kredit atau pembiayaan berdasarkan prinsip syariah, bank umum wajib mempunyai keyakinan berdasarkan analisis yang mendalam atau itikat dan kemampuan serta kesanggupan nasabah debitur untuk melunasi utangnya sesuai dengan yang diperjanjikan. Selanjutnya dalam penjelasan pasal ini disebutkan kredit adalah pembiayaan berdasarkan prinsip syariah yang diberikan oleh bank mengandung resiko, sehingga dalam pelaksanaanya bank harus memperhatikan asas - asas perkreditan atau pembiayaan berdasarkan prinsip syariah yang sehat. Pada asasnya, kasus kredit bermasalah ini adalah persoalan perdata yang menurut terminologi hukum perdata, hubungan antara debitor dengan kreditur (bank) selaku pemberi kredit merupakan hubungan utang piutang. Hubungan yang bersangkutan lahir dari perjanjian. Pihak debitur berjanji untuk mengembalikan pinjaman beserta biaya dan bunga, dan pihak kreditur memberikan kreditnya. Dalam hal kredit yang diberikan telah mengarah pada tanda - tanda timbulnya kredit macet, maka deteksi atas kredit macet dapat dilakukan secara sistematis dengan mengembangkan sistem "pengenalan diri", yaitu berupa daftar kejadian atau gejala yang diperkirakan dapat menyebabkan suatu pinjaman berkembang menjadi kredit macet. Apabila setelah bank berusaha melalui upaya prefentif namun akhirnya kredit yang telah dikeluarkannya menjadi kredit yang bermasalah, maka bank akan menggunakan upaya represif.

\section{PENUTUP}

\subsection{KESIMPULAN}

Berdasarkan hasil penelitian dan pembahasan yang telah diuraikan mengenai hal - hal yang berhubungan dengan Kredit Macet maka dapat disimpulkan sebagai berikut :

1. Tidak ada sebuah pemberian pinjaman kredit tanpa adanya sebuah angunan sebagai dasar sebuah jaminan kredit yang

diberikan, pada dasarnya angunan yang diperlukan untuk satu jenis kredit yang sama adalah sama untuk semua calon nasabah.

2. Hambatan yang terjadi dalam penyelesaian kredit macet dengan jaminan Hak Tanggungan masih belum dimanfaatkan secara optimal oleh kalangan perbankan khususnya yang berakibat bank tersebut tidak dapat memanfaatkan ketentuan Pasal 6 dan Pasal 20 Undang-Undang Hak Tanggungan. Adapun jalan keluarnya yang ditempuh dalam penyelesaian kredit macet dengan jaminan Hak Tanggungan adalah upaya penyelamatan kredit yang meliputi penjadwalan kembali (Rescheduling), persyaratan kembali (Reconditioning), penataan kembali (Restructuring) dan upaya penagihan kredit.

\subsection{SARAN}

Setelah membaca dan mempelajari permasalahan yang menjadi pembahasan dalam skripsi ini, maka penulis mencoba untuk memberikan beberapa saran sebagai berikut :

1. Sebaiknya pihak bank lebih tegas lagi dan berhati-hati dalam 
memberikan kredit kepada nasabah serta lebih mengoptimalkan penyelesaian kredit yang dijamin dengan Sertifikat atas tanah dengan menggunakan Dasar Hukum Pasal 6 Undang - Undang Hak Tanggungan dan dengan adanya pengawasan dari pihak bank atau kreditur akan lebih membantu terhadap usaha yang dilakukan debitur setiap waktu tertentu agar dapat membantu pencegahan kredit macet dan penyalagunaan kredit.

2. Kreditur harus memilih calon debitur yang memiliki kredibilitas dan karakter yang baik dan serta memiliki kemampuan dalam mengolah kekuangan yang telah dikucurkan oleh fihak bank untuk menjamin debitur atas hutang hutangnya pada kreditur dan Pengikatan kredit yang dibuat harus sempurna (jangan sampai terjadi cacat hukum) baik mengenai perjanjian pokoknya (perjanjian kredit) maupun semua perjanjian tambahanya.

\section{DAFTAR PUSTAKA}

\section{A. BUKU-BUKU}

Adrian Sutedi, "Hukum Perbankan" (Jakarta : Sinar Grafika, 2014).

Kasmir, "Dasar - Dasar Perbankan" (Jakarta : Rajawali Pers).

Arba, "Hukum Agraria Indonesia" (Jakarta : Sinar Grafika, 2015).

Mohammad Machfudh zarqoni, Hak Atas Tanah "Perolehan, Asal dan Turunannya, Serta Kaitannya dengan Jaminan Kepastian Hukum (Legal Guarantee) Maupun Perlindungan Hak Kepemilikannya (Propery Right)" (Jakarta : Prestasi Pustakarya, 2015)

R Subekti dan R Tjitrosudibo, "Kitab Undang - Undang Hukum Perdata" (Jakarta: Pradnya Paramita, 2009).
Neni Sri Imaniyati. "Pengantar Hukum Perbankan Indonesia” (Bandung : Revika Aditama 2010)

Abdurrahman dan Samsul Wahidin. "Beberapa catatab Tentang Hukum Jaminan dan Hak - Hak Jaminan Atas Tanah" (Bandung : Alumni, 1985).

Sentosa Sembiring. "Hukum Perbankan Edisi Revisi" (Bandung : Mandar maju, 2012).

Irma Devita Purnamasari. "Kiat - Kiat Cerdas, Mudah, dan Bijak memahami masalah Hukum Jaminan Perbankan" (Bandung :Mizan Pustaka, 2014).

\section{B. UNDANG - UNDANG}

1. Kitab Undang - Undang Hukum Perdata

2. Undang - Undang Nomor 4 Tahun 1996 tentang Hak Tanggungan

3. Undang - Undang Nomor 10 Tahun 1998 tentang Perbankan 